\title{
SIKAP TOKOH MASYARAKAT TERHADAP PERSALINAN TENAGA KESEHATAN
}

Dian Permatasari, Progaram Studi Kebidanan Universitas Wiraraja

dianashadi118@gmail.com

Dian Ika Puspitasari, Progrm Studi Ilmu Keperawatan Universitas Wiraraja

dianika.uwr@gmail.com

\section{ABSTRAK}

Upaya untuk mengendalikan angka kematian ibu dan bayi dapat dilakukan dengan usaha pemeliharaan dan pengawasan antenatal sedini mungkin, persalinan yang aman dan perawatan masa nifas yang baik. Tenaga kesehatan dapat memperkenalkan dan membuktikan eksistensi profesionalismenya kepada masyarakat dengan cara lebih menggalakkan penyuluhan tentang persalinan, pelatihan tentang kesehatan secara spesifik agar sikap masyarakat terhadap persalinan dan tenaga kesehatan dinilai lebih baik. Penelitian ini bertujuan untuk mengetahui gambaran sikap tokoh masyarakat terhadap persalinan tenaga kesehatan di Desa Bangkal Kecamatan Sumenep.

Metode yang digunakan adalah metode penelitian deskriptif, yaitu untuk mengetahui gambaran sikap tokoh masyarakat terhadap persalinan tenaga kesehatan. Populasi dalam penelitian ini adalah tokoh masayarakat di Desa Bangkal sebanyak 30 orang dengan jumlah sampel sebanyak 30 orang. tekinik sampling yang digunakan adalah total populasi. Metode pengumpulan data dengan menggunakan kuesioner, kemudian data dianalisis dengan distribusi frekuensi dalam bentuk prosentase (\%).

\section{Kata kunci : tokoh masyarakat, tenaga kesehatan, persalinan}

\section{PENDAHULUAN}

Masalah kesehatan ibu dan persalinan merupakan masalah nasional yang perlu mendapat prioritas utama, karena sangat menentukan kualitas sumber daya manusia pada generasi mendatang. Perhatian terhadap ibu dalam sebuah keluarga perlu mendapat perhatian khusus karena Angka Kematian Ibu (AKI) di Indonesia masih sangat tinggi, bahkan tertinggi diantara negara-negara ASEAN (Azwar, 2005).

Data yang diperoleh dari Dinas Kesehatan Kabupaten sumenep bahwa pada tahun 2017 angka cakupan kumulatif K1 sebesar $86 \%$, cakupan K4 baru mencapai $76,95 \%$, kunjungan neonatus mencapai 93,2. Dari studi pendahuluan yang dilakukan oleh penulis di Desa Bangkal Sumenep, belum tercapainya target persalinan tenaga kesehatan, salah satunya disebabkan karena sikap tokoh masyarakat sehingga masih ditemukan ibu bersalin ke dukun karena belum mengetahui pentingnya pemeriksaan kehamilan dan bersalin secara teratur kepada tenaga kesehatan.

Berdasarkan fenomena yang ada, sebagai tenaga kesehatan harus menerima dengan perasaan optimis dan positif. sehingga menggugah tenaga kesehatan untuk memperkenalkan dan membuktikan eksistensi profesionalismenya kepada masyarakat dengan cara lebih menggalakkan penyuluhan tentang persalinan, pelatihan tentang kesehatan secara spesifik agar sikap masyarakat terhadap persalinan dan tenaga kesehatan dinilai lebih baik dari sebelumnya.

\section{METODOLOGI PENELITIAN}

Pada penelitian ini responden diberikan angket seperti kuesioner dengan cara house to house yang sebelumnya telah dipilih oleh peneliti. Proses pengumpulan data ini memerlukan waktu efektif 2 (Dua) hari dengan rician yaitu, hari pertama memberi penjelasan maksud dan tujuan penelitian kemudian memberikan kuesioner pada responden dan hari kedua mengambil jawaban responden secara lengkap (100\%). Untuk diolah dan ditabulasi, sehingga bisa memberikan informasi tentang gambaran keputusan tokoh masyarakat dalam memilih tenaga kesehatan untuk tempat bersalin.

\section{HASIL DAN PEMBAHASAN}

Sikap tokoh masyarakat terhadap persalinan oleh tenaga kesehatan di Desa Bangkal Kecamatan Sumenep Kabupaten sumenep. Berdasarkan hasil penelitian menunjukkan bahwa sebagian besar responden mempunyai sikap Negatif.

Hasil penelitian tersebut dapat disebabkan karena beberapa fakta, salah satunya yaitu 
usia, karena usia yang dimiliki responden memiliki pengaruh yang cukup besar dalam mempengaruhi pola pikir seseorang dalam mengambil keputusan atau sikap. Dengan minimnya pendidikan dan bertambahnya usia maka tingkat kematangan yang dimiliki seseorang dalam berpikir akan semakin baik pula karena mereka akan selalu waspada dalam melakukan sesuatu dengan memikirkan segala resiko yang akan terjadi.

Jenis kelamin juga berpengaruh terhadap pola pikir dan cara menentukan sikap sehingga mayoritas Tokoh masyarakat mempunyai sikap Negatif terhadap persalinan tenaga kesehatan terlebih lagi ibu rumah tangga yang bersentuhan/berhubungan langsung dengan persalinan.

Hasil yang didapat dari penelitian yang dilakukan kepada 30 responden maka paling banyak berpendidikan dasar sebanyak 23 responden (75\%). Kurangnya tingkat pendidikan tokoh Masyarakat disebabkan oleh kebanyakan responden yang berpendidikan dasar sehingga rendahnya tingkat pendidikan berpengaruh kepada cara berpikir dan berpendapat sehingga responden atau tokoh masyarakat mempunyai sikap yang kurang baik terhadap persalinan tenaga kesehatan itu sendiri.

Pendidikan yang tinggi akan dapat menambah wawasan pengetahuan dimana hal ini akan ada hubungan tentang pendidikan seseorang yang tinggi maka orang tersebut dapat menerima informasi juga lebih mudah sehingga makin banyak pengetahuan yang ia miliki, apabila pendidikan seseorang itu rendah akan dapat menghambat perkembangan sikap seseorang terhadap suatu nilai yang baru diperkenalkan. Tokoh masyarakat yang berpendidikan kurang untuk mempengaruhi tokoh masyarakat yang lain untuk mendapatkan informasi, sehingga informasi yang mayoritas tokoh masyarakat dapatkan kurang khususnya tentang persalinan tenaga kesehatan.

Masyarakat di desa masih berpedoman pada kebiasaan yang turun temurun bahwa seorang ibu rumah tangga pada khususnya tidak perlu sekolah sampai jenjang yang tinggi, mereka mengutamakan pada pelajaran agama, mengaji dan mengurus rumah tangga. Disamping itu juga mata pencaharian tokoh masyarakat yang rendah menjadi salah satu faktor yang menghambat tokoh masyarakat untuk menempuh pendidikan yang lebih tinggi. Mayoritas mata pencaharian tokoh masyarakat yang tercantum pada halaman 50 adalah petani ( $23 \%$ ) yang membutuhkan waktu yang cukup lama dan rumit dan tenaga yang cukup untuk mengolahnya. Sehingga anak-anak yang seharusnya belajar dibangku pendidikan harus membantu orang tuanya bertani. Dan setelah dilakukan penelitian ternyata tokoh masyarakat di desa Bangkal mempunyai tingkat pendidikan yang rendah yaitu 23 orang atau $75 \%$.

Untuk menghadapi kondisi diatas upaya yang dapat dilakukan adalah memberikan penyuluhan dan motivasi pada tokoh masyarakat tentang pentingnya persalinan tenaga kesehatan, karena dengan diberikannya penyuluhan dapat menambah pengetahuan tokoh masyarakat tentang pentingnya persalinan di tenaga kesehatan, dan juga dengan adanya kader yang dibentuk di setiap dusun yang digunakan sebagai jembatan penghubung antara tenaga kesehatan dan tokoh masyarakat sehingga diharapkan dapat mempengaruhi tokoh masyarakat untuk membawa keluarganya bersalin ditenaga kesehatan.

Selain itu status sosial ekonomi tokoh masyarakat sangat mempengaruhi Dengan mempunyai pekerjaan tetap dan mapan secara otomatis kebutuhan dalam keluarga sebagian besar sudah dapat terpenuhi, tingkat ekonomi yang di maksud disini adalah kemampuan tokoh masyarakat untuk memenuhi kebutuhan hidupnya sehari-hari diantaranya untuk memenuhi pemeliharaan kesehatan ( Supriasi, 2001 : 33 ), semakin baik tingkat ekonomi tokoh masyarakat maka semakin baik pula kemampuannya dalam pemeliharaan kesehatan, tingkat ekonomi yang rendah berpengaruh terhadap sikap tokoh masyarakat terhadap persalinan tenaga kesehatan.

Dari hasil survey awal yang dilakukan kepada 19 responden, dan hasilnya didapat responden mempunyai sikap negatif sedangkan dari 11 responden (15\%) mempunyai sikap Positif. Hal ini disebabkan karena adanya faktor keyakinan, lingkungan, dan emosi. Emosi tersebut timbul karena seseorang menganggap bahwa obyek atau stimulus tersebut merupakan hal yang wajar.

Sebagaimana yang telah kita ketahui, sebagai manusia tidak dilahirkan dengan dilengkapi sikap akan tetapi sikap-sikap itu tumbuh bersama-sama pengalaman yang kita peroleh. Pengalaman yang diperoleh itu sendiri bisa senang, tidak senang atau keduanya, sebagai suatu bentuk reaksi individu terhadap lingkungannya. Dengan kata lain lingkungan juga dapat mempengaruhi seseorang dalam bersikap. 
Sikap merupaksan salah satu faktor yang mendorong seseorang untuk melakukan tindakan, mengingat sikap merupakan respon yang masih tertutup dari seseorang terhadap suatu stimulus atau obyek yang ada, sehingga sikap positif belum tentu dapat diwujudkan dalam bentuk tindakan atau perilaku. Maka dari itu sikap yang terdapat dalam diri seseorang masih dapat diubah apabila dalam diri seseorang tersebut didasari kesadaran dan keinginan yang ada dalam dirinya selain itu juga sikap yang dimiliki seseorang sewaktuwaktu dapat berubah karena pengaruh yang datang dari orang lain atau dari pengalamannya sendiri.

\section{KESIMPULAN}

Berdasarkan hasil penelitian dan pembahasan tentang sikap tokoh masyarakat terhadap persalinan tenaga kesehatan di Desa Bangkal Kecamatan Sumenep Kabupaten Sumenep dapat disimpulkan Hampir seluruhnya ( $85 \%$ ) sikap tokoh masyarakat terhadap tenaga kesehatan di Desa Bangkal Kabupaten Sumenep.

\section{SARAN}

\section{Bagi Peneliti}

Sekiranya perlu membuka diri mengenai pembelajaran tentang persalinan kepada masyarakat dengan cara meningkatkan kinerjanya dalam program-program Persalinan seperti mengadakan penyuluhan kesehatan yang diadakan oleh Posyandu maupun Puskesmas. Diharapkan dapat memberikan KIE dan sebagai bahan masukan dalm memberikan pelayanan tentang pentingnya persalinan tenaga kesehatan.

\section{Bagi Masyarakat}

Masyarakat diharapkan dapat memperoleh pengetahuan tentang pentingnya persalinan tenaga kesehatan sehingga masyarakat dapat memahami tentang persalinan yang baik dan aman

3. Institusi

Perlu adanya peningkatan kerja sama dengan masyarakat dalam pengoptimalan daerah binaan sebagai wujud dari keberadaan Tenaga Kesehatan. Dan diharapkan dapat digunakan sebagai masukan bagi lembaga pendidikan.

\section{Bagi Profesi}

Dengan diketahuinya hasil penelitian ini ikut berpartisipasi dalam program-program yang ada di Posyandu, Puskesmas maupun kegiatan yang ada di lingkungan sekitar sebagai wujud kepedulian Profesi dalam penanganan terhadap persalinan.

\section{DAFTAR PUSTAKA}

Ali, Zaidin (2000). Dasar-Dasar Tenaga Kesehatan Profesional. Widya Medika: Jakarta

Anonim. Tokoh Masyarakat, ciri-ciri tokoh Masyarakat dan sikap. Wikipedia Indonesia. www.wikipedia.com.2011.

Arikunto, Suhorsimi (1998). Prosedur Penelitian. Rineka Cipto. Jakarta.

Arikunto, S (2002). Pengantar Penelitian. PT. Rineka Cipta Jakarta.

Azwar, Saifuddin (2007). Sikap Manusia Teori dan Pengukurannya. Edisi. 2, Pustaka Pelajar : Yogyakarta

Dinas Kesehatan. ( 2011 ). Laporan Bulanan Per Desember. Sumenep. Dinkes Sumenep

Effendy, Nasrul (1997). Dasar-Dasar Kebidanan Kesehatan Masyarakat. Edisi 2, EGC: Jakarta

Gaffar, Ade Jumadi (1999). Pengantar Kebidanan Profesional Buku Kebidanan. EGC. Jakarta.

http :I RKPD KAB Sumenep 2011.com//2011/03/13/ Arsip Dinkes Sumenep. Laporan dan Data Persalinan Tenaga Kesehatan 2009-2011/ diakses pada tanggal 13 Pebruari 2011 jam 10.00 WIB.

http :I Kumpulan KTI Sutopo.com//2010/23/043/ Persalinan yang di tangani oleh tenaga kesehatan dan tenaga non kesehatan ( dukun ). / diakses pada tanggal 10 April 2011 jam 08.00 WIB.

Musaheri ( 2007 ) Pengantar Pendidikan. IRCiSoD : Batu Retno Bangun Tapan Djogjakarta.

Notoatmodjo (2003). Ilmu Kesehatan Masyarakat. PT. Rineka Cipta : Jakarta.

Nursalam (2000). Konsep dan Penerapan Metodologi Penelitian IImu Ksehatan. Salemba Medika. Jakarta.

Nursalam dan Pariani. S, 2003. Metodologi Riset Tenaga Kesehatan. Medika: Jakarta.

Prof. dr. S. Nasution, MA ( 2009 ) Sosiologi Pendidikan. Bumi Aksara : Jakarta

Prof. dr. Hanifa Wiknjosatro, Spog ( 2007 ) IImu Kebidanan. Yayasan bina pustaka Sarwono Prawirohardjo Tridasa Printer : Jakarta

Sastrawinata, Sulaiman. 1993. Obstetri Fisiologi. Bandung : Fakultas kedokteran Universitas Padjajaran Bandung.

Sastroasmoro, Sudigno dan Sofyan Ismail, 1995. Dasar-Dasar Metodologi Persalinan Klinis. Bina Aksara: Jakarta 